\title{
Empirical Analysis of Private Consumption in Lesotho: An ARDL Bound Test Approach
}

\author{
Moeti Damane \\ Central Bank of Lesotho, Maseru, Lesotho \\ Email: damane.moeti@gmail.com
}

How to cite this paper: Damane, $M$. (2018) Empirical Analysis of Private Consumption in Lesotho: An ARDL Bound Test Approach. Modern Economy, 9, 400-421. https://doi.org/10.4236/me.2018.93026

Received: October 9, 2017

Accepted: March 9, 2018

Published: March 12, 2018

Copyright (C) 2018 by author and Scientific Research Publishing Inc. This work is licensed under the Creative Commons Attribution International License (CC BY 4.0).

http://creativecommons.org/licenses/by/4.0/

\section{(c) (i) Open Access}

\begin{abstract}
The study empirically analyzes private consumption in Lesotho over the period 1982-2015 by employing an Autoregressive Distributed Lag bound test approach to cointegration. The results show that private consumption is positively influenced by the level of national disposable income in the short run and long run. The Marginal Propensity to Consume is highly significant and is less than 1. This proves the Keynesian consumption theory in Lesotho. The research findings reveal that increased government expenditure crowds out private consumption in the short run and long run. A growth in the level of inflation has no effect on private consumption. An expansion in the rate on deposits positively affects private consumption in the short run. The policy recommendation given the results of the study is that the government of Lesotho should implement initiatives aimed at increasing employment as well as private sector development as espoused in the country's National Strategic Development Plan.
\end{abstract}

\section{Keywords}

Consumption, GDP, CPI, ARDL, Bounds Test

\section{Introduction}

Scholarly investigation into the concept of consumption can be traced as far back as 1936 to Keynes' General Theory of Employment, Interest and Money which is widely regarded as the bedrock of macroeconomics. It is in light of this that [1] and [2] highlighted that the theory of consumption was at the heart of Keynes' General Theory model. Moreover, relative to any other speciality fields in macroeconomics, the theory of consumption is the most influenced by the rational expectations revolution. Reference [3] advanced that the study of consumption continues to enjoy great prominence in the academic exploration of 
households' choice of how much of their income to consume and how much of it to save. Reference [4] coupled with [5], defined consumption as goods and services purchased by households. Ergo, by definition, consumption is a critical factor in explaining economic booms and recessions. Reference [6] concurred, and noted that for a given level of income, consumption determines savings and therefore investment. Variations in consumption could thus be sources of economic shocks and therefore, taking a closer look at consumption is important in order to understand, inter alia, the effects of government policies on investment and economic growth.

It is important to highlight that this research is aware of the fact that there have been other papers such as [7] [8] [9] and [10] coupled with [11] that look at the relationship between consumption and its determinants in African countries including Lesotho. While these studies are informative, the comparatively varying degrees of development amongst African countries, their distinct geographical and economical make up ${ }^{1}$ and the ever evolving nature of consumption patterns, a point highlighted by [3], warrants that continued and up to date studies of consumption in Lesotho be undertaken. In addition, [7] only looked at the consumption patterns in Lesotho without focusing on factors that drive consumption. Reference [12] indicated that the Government of Lesotho (GoL) is the main employer in the country's formal sector and thus one of the most significant sources of household income. This point was not explored by [11].

A review of studies by domestic scholars reveals that the role of government expenditure in explaining private consumption patterns is not widely explored. The purpose of this paper is therefore to contribute to the general body of economic literature on consumption by empirically analyzing the relationship between private consumption and a select group of variables including government expenditure and the rate on deposits in Lesotho so as to provide accurate, informed and country specific policy directions. In order to do this, the paper employs the use of an Autoregressive Distributed Lag (ARDL) bounds testing approach to cointegration and estimates an Error Correction Model (ECM) on Lesotho's annual time series data covering the period 1982-2015.

The study proceeds as follows: Section 2 presents a discussion on the income and consumption distribution in Lesotho in 2002/2003 and 2010/2011. Section 3 is the literature review. Section 4 provides the analytical framework. Section 5 outlines the empirical results. Lastly, Section 6 concludes the study.

\section{Income and Consumption Distribution in Lesotho in $2002 / 2003$ and $2010 / 2011^{2}$}

This section examines the distribution of income, sources of income and con-

\footnotetext{
${ }^{1}$ Lesotho is a landlocked country that is completely surrounded by South Africa. It also has its currency, the Loti pegged at par with the South African Rand under the Common Monetary Area (CMA) agreement.

${ }^{2}$ The periods are informed by availability of data from Lesotho's Household Budget Surveys of 2002/03 and 2010/11 conducted by the National Bureau of Statistics (BoS).
} 
sumption patterns in Lesotho for the periods 2002/2003 and 2010/2011. In the discussion, household income is defined as the sum of employee income, self-employment or entrepreneurial income, property income, transfers income and other income. Consumption expenditure on the other hand is explained to cover all monetary and non-monetary expenditure by households on goods and services for consumption as well as the value of goods received as income in-kind and consumed by the households [13]. Table 1 and Table 2 present the percentage distribution of households by main source of income and urban/rural residence for the period 2002/2003 and 2010/2011, respectively.

For the period 2002/2003, the main source of household income in Lesotho was the private sector that constituted 27.3 per cent of the national average. This was followed by income from the farming sector that accounted for 25.4 per cent of the national average and income from the public sector that made up 13 per

Table 1. Percentage distribution of households by main source of income and urban/ Rural residence, 2002/2003.

\begin{tabular}{cccccccc}
\hline $\begin{array}{c}\text { Income } \\
\text { Category }\end{array}$ & $\begin{array}{c}\text { Maseru } \\
\text { Urban }\end{array}$ & $\begin{array}{c}\text { Other } \\
\text { Urban }\end{array}$ & $\begin{array}{c}\text { Rural } \\
\text { Lowlands }\end{array}$ & $\begin{array}{c}\text { Rural } \\
\text { Foothill }\end{array}$ & $\begin{array}{c}\text { Rural } \\
\text { Mountain }\end{array}$ & $\begin{array}{c}\text { Rural } \\
(\mathrm{S} . \mathrm{R} . \mathrm{V})^{3}\end{array}$ & Lesotho \\
\hline From Public Sector & 22.10 & 20.5 & 4 & 6.3 & 3.1 & 2.7 & 13 \\
From Private Sector & 49.2 & 32.5 & 18.4 & 14.9 & 12.4 & 23.5 & 27.3 \\
Farming & 1.8 & 5.6 & 44.2 & 47.8 & 60.4 & 29.7 & 25.4 \\
Other HH Business & 11.1 & 14.2 & 4.2 & 5.2 & 3.6 & 7 & 9.1 \\
Pensions & 2.0 & 2.8 & 3 & 2.3 & 0.7 & 1.1 & 2.3 \\
Remittances & 2.8 & 11.2 & 14.2 & 12.9 & 9.4 & 15.8 & 10.7 \\
Other HH Business & 10.9 & 13.1 & 12 & 10.5 & 10.3 & 20.2 & 12.2 \\
\hline
\end{tabular}

Source: [14].

Table 2. Distribution of households by main source of income and urban/rural residence, $2010 / 2011$.

\begin{tabular}{cccc}
\hline Main Source of Income & Urban & Rural & Total \\
\hline $\begin{array}{c}\text { Wages and salaries from public sector } \\
\text { Wages and salaries from private sector }\end{array}$ & 21.9 & 6.90 & 10.8 \\
Farming & 37.1 & 16.90 & 22.2 \\
Casual work & 3.1 & 36.80 & 28 \\
Household business & 9.9 & 10.40 & 10.3 \\
Pensions & 11.4 & 4.70 & 6.5 \\
Remittances from abroad & 2.7 & 2.40 & 2.5 \\
Other remittances & 3.3 & 5.10 & 4.7 \\
Social assistance & 4.9 & 4.40 & 4.6 \\
Other & 2 & 6.90 & 5.6 \\
\hline
\end{tabular}

Source: [13].

${ }^{3}$ Senqu River Valley. 
cent of the national average. The majority of households that earned their income from the farming sector were located in the rural areas while those that earned most of their income from the private sector and public sector were found in the urban areas. Similarly, for the period 2010/2011, households from the rural areas received most of their income from the farming sector while those from the urban areas earned most of their income from the private sector and public sector. However, unlike 2002/2003, in 2010/2011 on a country wide basis, most of Lesotho's households earned their income from the farming sector followed by those that generated their income from the private sector. Table 3 and Table 4 present the percentage distribution of consumption expenditure by households on specified commodity items for the period 2002/2003 and 2010/2011, respectively.

Table 3. Percentage distribution of consumption expenditure by households on specified commodity item by Urban/Rural, 2002/2003.

\begin{tabular}{cccccccc}
\hline $\begin{array}{c}\text { Commodity } \\
\text { Group }\end{array}$ & $\begin{array}{c}\text { Maseru } \\
\text { Urban }\end{array}$ & $\begin{array}{c}\text { Other } \\
\text { Urban }\end{array}$ & $\begin{array}{c}\text { Rural } \\
\text { Lowlands }\end{array}$ & $\begin{array}{c}\text { Rural } \\
\text { Foothill }\end{array}$ & $\begin{array}{c}\text { Rural } \\
\text { Mountain }\end{array}$ & $\begin{array}{c}\text { Rural } \\
(\text { S.R.V) }\end{array}$ & Lesotho \\
\hline Food and Beverage & 34.9 & 42.9 & 47.9 & 47.6 & 58.1 & 50.7 & 44.3 \\
$\begin{array}{c}\text { Clothing and Footwear } \\
\text { Rent, Fuel and Power }\end{array}$ & $\begin{array}{c}10.3 \\
7.7\end{array}$ & 14.3 & 16.3 & 20.1 & 21.8 & 19 & 15.3 \\
$\quad \begin{array}{c}\text { Furniture and } \\
\text { Household Service }\end{array}$ & 10.3 & 12.3 & 6.2 & 5.9 & 5.2 & 8.8 & 6.5 \\
$\begin{array}{c}\text { Medical care and Health } \\
\quad\end{array}$ & 2.7 & 1.7 & 1.8 & 1.8 & 1.1 & 2.3 & 1.9 \\
$\begin{array}{c}\text { Transport and } \\
\text { Communication }\end{array}$ & 17.9 & 9.3 & 7 & 6.1 & 2.8 & 3.7 & 9.7 \\
$\begin{array}{c}\text { Recreation, Education } \\
\text { and Culture }\end{array}$ & 7.6 & 6.9 & 5.1 & 7.5 & 3.5 & 3.3 & 6.3 \\
$\begin{array}{c}\text { Miscellaneous Goods } \\
\text { and Services }\end{array}$ & 8.8 & 6.1 & 10.7 & 6.8 & 5.2 & 7.7 & 7.5 \\
\hline
\end{tabular}

Source: $[14]$

Table 4. Percentage distribution of consumption expenditure by households on specified commodity item by Urban/Rural residence, 2010/2011.

\begin{tabular}{cccc}
\hline Commodity Items & Urban & Rural & Total \\
\hline Food and Non Alcoholic Beverages & 35.8 & 57 & 49.4 \\
Alcoholic Beverages and Tobacco & 4.9 & 6.2 & 5.7 \\
Clothing and Footwear & 6.5 & 5.7 & 0.6 \\
Housing, Electricity, Gas and Other Fuel & 20.4 & 13.9 & 16.2 \\
Health & 1.2 & 0.7 & 0.9 \\
Transport Services & 8.3 & 5.1 & 6.2 \\
Communication & 1.9 & 0.8 & 1.2 \\
Recreation and Culture & 1.1 & 0.7 & 0.9 \\
Education & 13.3 & 6.5 & 8.9 \\
Restaurants and Hotels & 0.6 & 0.2 & 0.3 \\
Furniture and Furnishings & 2.3 & 1.6 & 1.9 \\
Miscellaneous Goods and Services & 3.7 & 1.6 & 2.4 \\
\hline
\end{tabular}

Source: [13]. 
In 2002/2003, 44.3 per cent of Lesotho's consumption expenditure was on food and beverages followed by clothing and footwear at 15.3 per cent. The most consumed commodity in the period 2010/2011 was food and non-alcoholic beverages at 49.4 per cent while the second most consumed commodity in the same period was housing, electricity, gas and other fuels at 16.2 per cent. The least consumed commodity in 2002/2003 was medical care and health at 1.9 per cent while the least consumed commodity in 2010/2011 was restaurants and hotels at 0.3 per cent. Figure 1 shows the relationship between Lesotho's Gross Domestic Product (GDP) and final private consumption expenditure for the period 1982 to 2014. During the period, the annual GDP grew by an average rate of 4 per cent while the level of private consumption grew at an average rate of 6 per cent. In addition, the level of private consumption constituted approximately 50 per cent of GDP over the period 1982 to 2014 . The persistent positive relationship between the level of GDP and the level of private consumption appears to suggest that growth in GDP leads to increases in household income and therefore a rise in the level private consumption over time.

\section{The Literature Review}

\subsection{Theoretical Literature}

\subsubsection{Keynesian Consumption Theory}

Reference [2] and [9] explained that according to Keynes' consumption theory, current consumption expenditures are determined by current disposable income such that an increase in household disposable income will lead to a rise in consumption but at a less than proportional margin. Keynes called this change in consumption due to a change in income, the marginal propensity to consume

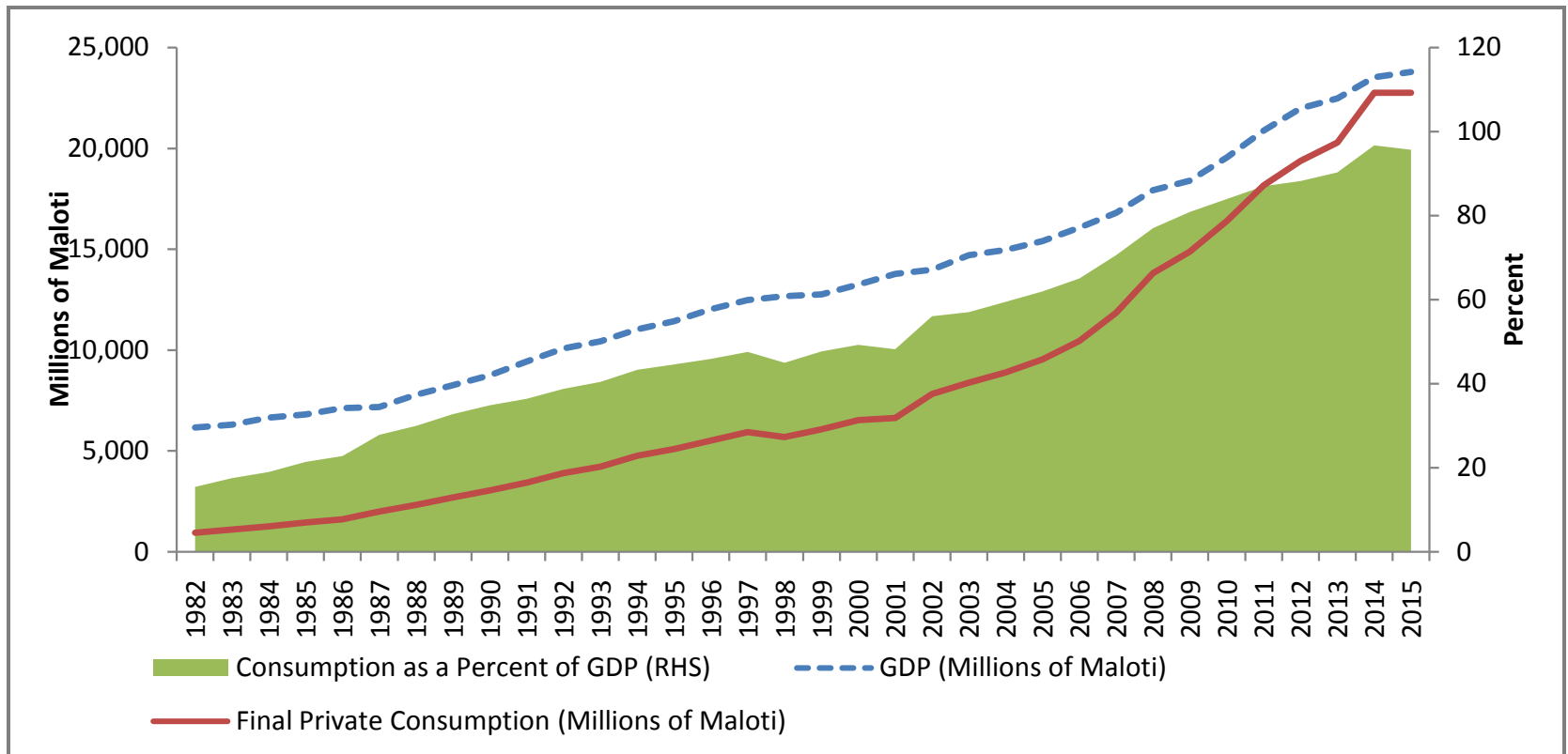

Source: Central Bank of Lesotho

Figure 1. GDP and final private consumption expenditure in Lesotho, 1982-2014. 
(MPC). Reference [9] together with [5] underscored that in Keynes' consumption function; the MPC is positive but is less than one. This relationship can be represented by Equation (1) where $C$ is consumption, $Y$ is disposable income, $C_{0}$ is a constant and $c$ is the MPC.

$$
C=C_{0}+c Y, C_{0}>0,0<c<1
$$

Under the Keynesian consumption theory, the interest rate has no impact on consumption decisions given that the income and substitution effects of the interest rate eliminate each other [15].

\subsubsection{Life Cycle Permanent Income Hypothesis}

Reference [2] explained that the life cycle permanent income hypothesis is the result of two initially distinct theories of consumption; the life cycle model and the permanent income hypothesis that were eventually merged into one. The life cycle model was developed by Franco Modigliani, Albert Ando and Richard Brumberg in the mid-1950s. The permanent income hypothesis on the other hand was developed by Milton Friedman in 1957. Reference [5] noted that the life cycle model and permanent income hypothesis enhanced the simple Keynesian consumption model by taking into consideration time horizon and psychological aspects of consumption. According to [2], the life cycle model placed emphasis on the idea of consumption smoothing over time by highlighting that income from labour is often low in the early work years and higher in the later work years before it drops at retirement. To smooth consumption, consumers borrow during periods of low income, repay the loans and build wealth during high income years and use accrued savings during retirement to finance consumption. To explain Friedman's permanent income hypothesis; [5] posited that Friedman cited permanent income, which is equivalent to the average income of past years as the key element in determining private consumption behaviour. Reference [2] explained this further by stating that Friedman's focus was on consumer patterns when income fluctuated over time; whether due to life-cycle effects, business cycles or other factors. Friedman distinguished between permanent income $e^{4}$, transitory income ${ }^{5}$, permanent consumption ${ }^{6}$ and transitory consumption ${ }^{7}$. The conclusion was that permanent consumption depends on permanent income while the transitory consumption is independent from income and is captured in the random error term in a consumption regression function.

\subsection{Empirical Literature}

Empirical research on the determinants of private consumption is vast, as depicted in Appendix 1).

${ }^{4}$ This is the amount a household could consume without reducing its wealth. This is the annual return on households' stocks of human and nonhuman wealth (Parker, 2010).

${ }^{5}$ These are positive or negative deviations from the level of permanent income (Parker, 2010).

${ }^{6}$ This is part of consumption that is planned and steady (Parker, 2010).

${ }^{7}$ This is part of consumption that is unexpected or irregular such as unexpected medical bills (Parker, 2010). 
Reference [8] explored the relationship between GDP and personal consumption in Nigeria using time series data from 1994-2007. Personal consumption is modelled as a function of GDP with the use of simple linear regression equation and is estimated using the ordinary least squares (OLS) approach. The study discovered that the relationship between personal consumption and GDP in Nigeria was statistically insignificant meaning that a change in Nigeria's GDP had an insignificant effect on the level of personal consumption expenditure.

Reference [15] investigated the dynamics of private consumption in China from 1980 to 2008 using cross country data that resulted in an unbalanced panel of 39 economies for a total of 515 observations. They regressed private consumption as a share of GDP on household income and public consumption (both as a share of GDP), the level of per capita GDP, real GDP growth, real interest rates, inflation, the change in terms of trade, the old-age dependency ratio, the change in the real effective exchange rate, the share of employment in the services sector, a measure of past foreign financing, and a measure of financial development. The model was estimated using the Generalized Method of Moments (GMM) estimator. The study obtained a positive and significant relationship between private consumption and GDP per capita, public consumption (as a share of GDP), real GDP growth, change in terms of trade and external financing, respectively. In addition, they discovered that the relationship between private consumption and real interest rate, old-age dependency ratio, financial development, share of employment in the service sector, change in real effective exchange rate and household income (as a share of GDP) was negative and statistically significant.

Reference [9], much like [8] applied the OLS approach to estimate a consumption function for Kenya using annual time series data from 1992-2011. In the study, household consumption is regressed on income. The results conformed to Keynesian consumption theory and obtained a statistically significant and positive MPC.

Reference [10] examined the relationship between consumption and household real wealth (housing and stock prices) across nine South African provinces over the period from 1995-2011 by employing panel cointegration techniques. The results of the study found a positive and significant relationship between provincial consumption and housing prices and between provincial consumption and stock prices. In addition, it was discovered that the MPC respective to stock wealth was larger and much more significant than that of housing wealth. This means a change in stock prices had a much higher impact on provincial consumption than housing prices.

Reference [16] investigated the long run relationship between private consumption per capita (expressed in the form of household final consumption expenditure), adjusted net national income per capita and GDP per capita (as a proxy for the level of standard of living) using time series cross-sectional data from 79 countries from 1980 to 2010 . The countries were divided into three cat- 
egories, namely; low, middle and high depending on their income level. The research discovered that there is a positive relationship between consumption and income. However, the association between income and consumption was found to be greater in low and high income countries relative to those of middle income. The association between consumption, income and GDP was found to be positive and significant across all classes of countries in the panel and was higher for low and middle income countries.

Reference [5] employed annual time series data from 1978-2012 to estimate a private consumption function for Iran using the ARDL approach. In the study, total private consumption is a function of GDP and inflation. The study discovered the existence of a positive and statistically significant relationship between the level of private consumption and GDP. Furthermore, it obtained a negative and significant relationship between the level of inflation and consumption. Noteworthy, the impact of GDP on consumption in the short-run was found to be less than it was in the long run. In addition, there existed a higher effect of inflation on GDP in the long run than in the short run meaning that consumers adjusted their consumption in the long run after they corrected their expectations.

Reference [11] investigated the relationship between real private domestic consumption, Inflation, real gross domestic product, real gross national income, real household disposable income, real prime lending rate, narrow money and broad money in Lesotho using the ARDL approach and annual time series data from 1982 to 2013. The study discovered that higher income was associated with higher private consumption. Moreover, higher inflation and higher interest rates reduce private consumption.

The empirical review of the literature indicates that studies of the relationship between private consumption and a select group of other variables across developed and developing countries yield diverse results. This is especially true considering the differences in periods and methodologies used. A general conclusion in most of the studies is that there is a positive relationship between consumption and income while the relationship between consumption and inflation is negative. Another general consistency among the reviewed studies is the inclusion of income and inflation as key variables in consumption models. However the role of government expenditure in explaining private consumption patterns is not widely explored in the studies reviewed. It is the intention of the study to fill this gap in the literature.

\section{Analytical Framework}

In order to investigate the relationship between private consumption, national disposable income, inflation, government expenditure and the rate on deposits, the study uses annual time series data from 1982-2015. The data was obtained from the Central Bank of Lesotho (CBL) data base and the World Bank (WB) World Development Indicators (WDI). This paper expresses Lesotho's hypothe- 
sized consumption model in Equation (2).

$$
\text { PCON }_{t}=f\left(N D I_{t}, G O V E X P_{t}, D R_{t}, I N F L_{t}\right)
$$

where $P C O N$ is private consumption, $N D I$ is the national disposable income, GOVEXP is the total government expenditure, $D R$ is the interest rate on deposits and INFL is the rate of inflation.

\subsection{Model Specification}

For purposes of examining the long run relationship between private consumption and its determinants, the study makes use of the ARDL approach with the following form:

$$
\begin{aligned}
\Delta \ln \text { PCON }_{t}= & \beta_{0}+\beta_{1} \ln \text { PCON }_{t-1}+\beta_{2} \ln N D I_{t-1}+\beta_{3} \ln \text { GOVEXP }_{t-1} \\
& +\beta_{4} D R_{t-1}+\beta_{5} \text { INFL }_{t-1}+\sum_{i=1}^{p} \pi_{1} \Delta \ln \text { PCON }_{t-i} \\
& +\sum_{i=1}^{p} \pi_{2} \Delta \ln N D I_{t-i}+\sum_{i=1}^{p} \pi_{3} \Delta \ln G O V E X P_{t-i} \\
& +\sum_{i=1}^{p} \pi_{4} \Delta D R_{t-i}+\sum_{i=1}^{p} \pi_{5} \Delta I N F L_{t-i}+\theta W+\varepsilon_{t}
\end{aligned}
$$

where $t$ is the time period, $\beta_{0}-\beta_{5}$ are the coefficients explaining the elasticities of the explanatory variables in the long run while $\pi_{0}-\pi_{5}$ are the coefficients explaining the elasticities of the explanatory variables in the short run. All of the variables except the deposit rate and the inflation rate are expressed as natural logs. PCON, NDI, GOVEXP, DR and INFL are as previously explained under Equation (2), $\mathcal{E}$ is the white noise error term and $\mathrm{W}$ is any exogenous variable affecting consumption in Lesotho. On a priori grounds, the variables used in Equation (3) and their expected signs are presented in Table 5.

Reference [9] [17] [18] [19] together with [5], discovered that the impact of income on private consumption expenditure is positive and highly significant. These findings are in line with the expectations of this paper. The impact of government spending on private consumption is expected to yield ambiguous results. According to [20] [21] and [22], government expenditure can in some cases result in a crowding in of private consumption while in other cases it crowds it out. Reference [23] coupled with [24] indicated that there exists a negative relationship between inflation and consumption such that when prices rise in the present period compared to the last, this translates into uncertainty and the erosion of consumer confidence. The response is a greater need for

Table 5. Data series, sources and expected sign.

\begin{tabular}{cccc}
\hline Variable & Descriptor & Database/Source & Expected Sign \\
\hline PCON & Private Consumption & CBL & \\
NDI & National Disposable Income & CBL & Positive \\
GOVEXP & Government Expenditure & WB-WDI & Ambiguous \\
DR & Deposit Interest Rates & WB-WDI & Negative \\
INFL & Inflation Rate & WB-WDI & Negative \\
\hline
\end{tabular}


savings and reserve funds. Moreover, inflation leads to a postponement of discretionary expenditures and reduces the level of goods demanded as resources are devoted to necessities rather than desirable but non-essential goods and services. These conclusions are in sync with this paper's a priori expectations. It is expected that increases in the rate of deposits will reduce disposable income as resources are shifted towards saving to take advantage of the higher returns and to also provide funds for investment in Lesotho. A similar negative relationship between interest rates on deposits and private consumption was found by [25], [26], as well as [27].

The ARDL procedure used in this study employs the bounds testing approach to cointegration and error-correction modelling technique developed by [28] [29] and [30]. The approach has a number of advantages. It can be applied irrespective of whether variables are $\mathrm{I}(0)$ or $\mathrm{I}(1)^{8}$. It is efficient; especially for small sample sizes and it can be used to develop interpretations for both long and short run relationships between variables. In order to determine the presence of a long-run relationship between the variables of interest, the bounds test to cointegration performs a joint significance test for

$$
H_{0}: \beta_{1}=\beta_{2}=\beta_{3}=\beta_{4}=\beta_{5}=0
$$

against the alternative hypothesis of

$$
H_{1}: \beta_{1} \neq \beta_{2} \neq \beta_{3} \neq \beta_{4} \neq \beta_{5} \neq 0
$$

using the Wald test (F-statistics). The F-statistics from the Wald test is compared to the asymptotic critical values obtained from [30]. Cointegration is concluded to exist if the F-statistics from the Wald test is greater than the asymptotic critical values supplied by Pesaran for both upper bounds and lower bounds, otherwise there is no cointegration. Once cointegration has been proven to exist, the short-run and long-run dynamics can be examined following the estimation of the ARDL model in Equation (3). The long run model is formulated as follows:

$$
\begin{aligned}
\Delta \ln \operatorname{PCON}_{t}= & \beta_{0}+\beta_{1} \ln \mathrm{PCON}_{t-1}+\beta_{2} \ln N D I_{t-1} \\
& +\beta_{3} \ln \operatorname{GOVEXP}_{t-1}+\beta_{4} D R_{t-1}+\beta_{5} I_{N F L_{t-1}}+\mu_{i}
\end{aligned}
$$

The ARDL specification for the short-run dynamics is obtained from formulating an error correction model in the following form:

$$
\begin{aligned}
\Delta \ln \text { PCON }_{t}= & \pi_{0}+\sum_{i=1}^{p} \pi_{1} \Delta \ln \text { PCON }_{t-i}+\sum_{i=1}^{p} \pi_{2} \Delta \ln N D I_{t-i} \\
& +\sum_{i=1}^{p} \pi_{3} \Delta \ln \operatorname{GOVEXP}_{t-i}+\sum_{i=1}^{p} \pi_{4} \Delta D R_{t-i} \\
& +\sum_{i=1}^{p} \pi_{5} \Delta I N F L_{t-i}+E C T_{t-i}+\theta W+\mu_{i}
\end{aligned}
$$

In Equation (4) and (5), all the variables are as previously defined. $\mu_{i}$ is the error term and $\Omega$ is the coefficient of the error correction term $\left(E C T_{t-i}\right)$. The Error Correction Term (ECT) captures the speed of adjustment necessary to restore equilibrium in the dynamic model given a shock to the system in the previous period. The ECT coefficient should be statistically significant with a nega${ }^{8}$ Pretesting is done only to ensure that the variables are not I(2). 
tive sign.

\subsection{Unit Root Tests}

Reference [31] explained that unit root testing is not a prerequisite in the use of the ARDL cointegration technique. However, in order to avoid ARDL model crash in the event that an integrated stochastic trend of I(2) is present, unit root testing should be conducted. The study makes use of the Augmented Dickey and Fuller(ADF) as explained in [32] and [33] and Phillips-Perron (PP) tests as explained in [34] in order to determine the order of integration of the variables since the bounds test cannot be applied for series that are I(2). In this case, the PP test accompanies the ADF because it is non-parametric and corrects for any serial correlation and heteroskedasticity in the errors.

\section{The Empirical Results}

\subsection{Unit Root Procedure}

The findings of the unit root tests using the ADF and PP tests are presented in Table 6. Private consumption, national disposable income and government expenditure are stationary at first difference at the 1 per cent significance level under both the ADF and PP tests. The deposit rate is stationary at levels at the 5 per cent significance level under the ADF test but non-stationary at levels under the PP test. The deposit rate is first difference stationary under both the ADF and PP tests. Inflation on the other hand is stationary at levels at the 1 per cent significance level under the ADF and the PP tests, respectively. The ARDL model is therefore estimated with a combination of $\mathrm{I}(0)$ and $\mathrm{I}(1)$ variables.

\subsection{Cointegration Test Results}

In order to conduct the bounds test to cointegration, Equation (3) is estimated under an ARDL specification with a $(1,0,0,0,1)$ lag order. Table 7 presents the cointegration test results. The results indicate that the null hypothesis of no cointegration is rejected since the calculated F-statistics from the Wald test (7.118528) exceeds the upper bound critical values at all levels of significance.

Table 6. ADF and PP unit root test results.

\begin{tabular}{ccccc}
\hline & \multicolumn{2}{c}{$\mathrm{H}_{0}$ : non-stationary in levels } & \multicolumn{2}{c}{$\mathrm{H}_{0}$ : non-statioinary in first differences } \\
\hline Variable & ADF Statistic & PP Statistic & ADF Statistic & PP Statistic \\
\hline PCON & 0.620427 & 0.547361 & $-4.906727^{* * *}$ & $-4.879549^{* * *}$ \\
NDI & -2.285811 & -2.327518 & $-5.000184^{* * *}$ & $-5.027184^{* * *}$ \\
GOVEXP & -2.732499 & -2.818728 & $-4.705376^{* * *}$ & $-4.696117^{* * *}$ \\
DR & $-3.689404^{* *}$ & -2.216151 & $-4.954089^{* * *}$ & $-6.282578^{* * *}$ \\
INFL & $-6.029111^{* * *}$ & $-6.869833^{* * *}$ & - & - \\
\hline
\end{tabular}

Notes: The asterisks ${ }^{* *}$ and ${ }^{* *}$ denote significance level at $1 \%$ and $5 \%$ for the ADF and PP test of unit root. The null hypothesis is that the series are non-stationary. 
The asymptotic critical values for the bounds test were obtained from [35] under restricted intercept and no trend and not from [30] since the study's sample size is small.

\subsubsection{Long Run Analysis}

The results of the long run model together with the respective diagnostic tests are presented in Table 8. The diagnostic tests indicate that the Durbin Watson (DW) test for the presence of autocorrelation is closer to 2, meaning that there is no autocorrelation amongst the residuals. The Breusch-Godfrey (BG) LM test for serial correlation also reflects that there is no serial correlation amongst the errors. Furthermore, The Jarque Bera (JB) test for normality and the Breusch-Pagan-Godfrey (BPG) heteroskedasticity test confirm that the errors are white noise. In addition, the coefficients of the model are statisically different from zero as depicted by the Wald test. The $\mathrm{R}^{2}$ is computed to denote how well the model fits the data. From Table 8 , the $\mathrm{R}^{2}$ shows that approximately 50 per cent of the variation in private consumption is explained within the model. The Ramsey RESET test indicates that the model is well specified and that there are no omitted variables in the model. The stability of the long-run and short-run

Table 7. Cointegration test results.

\begin{tabular}{lccccc}
\hline \multicolumn{5}{c}{ Bound test for cointergration } \\
\hline \multicolumn{5}{c}{ Critical value bounds of the F statistic: restricted intercept and no trend } \\
\hline \multicolumn{4}{c}{ 90\% level } & \multicolumn{3}{c}{$\mathbf{9 5 \% \text { level }}$} & \multicolumn{3}{c}{$\mathbf{9 9 \%}$ level } \\
\hline $\mathrm{I}(0)$ & $\mathrm{I}(1)$ & $\mathrm{I}(0)$ & $\mathrm{I}(1)$ & $\mathrm{I}(0)$ & $\mathrm{I}(1)$ \\
2.525 & 3.560 & 3.058 & 4.223 & 4.280 & 5.840 \\
F-Statistics: 7.118528 & & & & \\
Sample size: 33 & & & & \\
K is the number of regressors: 4 & & & & \\
\hline
\end{tabular}

Table 8. Estimated long-run model.

\begin{tabular}{ccc}
\hline \multicolumn{1}{c}{ Variable } & Coefficient & t-statistic \\
\hline D(LNDI) & 0.993413 & $2.408464^{* *}$ \\
D(LGOVEXP) & -0.428709 & $-1.989099^{* *}$ \\
INFL & -0.008841 & -1.422563 \\
D(DR) & 0.003399 & 0.550195 \\
Diagnostics Tests & & \\
$\mathrm{R}^{2}=0.497207$ & & \\
Adj $\mathrm{R}^{2}=0.400516$ & & \\
Durbin-Watson $=1.870691$ & \\
Jarque-Bera $=$ [2.481210] (0.289209) & \\
Wald Test $=$ [7.118528] (0.0001) & \\
Breusch-Godfrey Serial Correlation LM Test $=[0.233687](0.7934)$ & \\
Heteroskedasticity Test: Breusch-Pagan-Godfrey $=[1.575603](0.1957)$ &
\end{tabular}

Notes: Values in brackets are F-statistics while values in parentheses are p-values. The asterisks ${ }^{\star *}$ denote significance level at $5 \%$. ARDL $(1,0,0,0,1)$ based on the Akaike Information Criterion (AIC). 
model coefficients is checked through the cumulative sum (CUSUM) and cumulative sum of squares (CUSUMQ) tests. The results of the CUSUM and CUSUMQ tests, presented in Appendix 5), show that the CUSUM of recursive residuals and CUSUMQ of recursive residuals are within the critical bounds, meaning that all coefficients are stable over the sample period.

The results of the estimated long-run model show that there is a positive relationship between national disposable income and private consumption. The coefficient of national disposable income is 0.993 and is statistically significant at the 5 per cent level. This means that a 1 per cent increase in national disposable income will result in a 0.993 per cent growth in consumption in the long run. These findings are in line with a priori expectations. Furthermore, they are in harmony with the conclusions of [9] [17] [18] [19]. It is also important to note that the size of the national disposable income coefficient is less than 1 and thus proves the existence of the Keynesian theory of consumption in Lesotho. There is a negative and statistically significant relationship at the 5 per cent level between government expenditure and private consumption. A 1 per cent growth in government expenditure will lead to a 0.429 per cent decline in private consumption. This suggests that government expenditure crowds out private consumption in the long run. The coefficients of inflation and the rate on deposits are found not to be significant in the long run.

\subsubsection{Short-Run Analysis}

Table 9 presents the estimated Error Correction Model (ECM) for private consumption as articulated in Equation (5) as well as its corresponding diagnostic tests.

The results of the diagnostic tests show that the coefficients are statistically different from zero and the residuals are white noise. The estimated model

Table 9. Error correction model.

\begin{tabular}{|c|c|c|}
\hline Variable & Coefficient & t-statistic \\
\hline $\mathrm{D}(\mathrm{LNDI}, 2)$ & 0.606101 & $3.712062^{\star * *}$ \\
\hline D(LGOVEXP, 2) & -0.261564 & $-2.897323^{* * *}$ \\
\hline $\mathrm{D}(\mathrm{INFL})$ & -0.005394 & -1.580452 \\
\hline $\mathrm{D}(\mathrm{DR}, 2)$ & 0.007100 & $2.290102^{* *}$ \\
\hline CointEq(-1) & -0.610120 & $-3.803741^{* * *}$ \\
\hline \multicolumn{3}{|l|}{ Diagnostics Tests } \\
\hline \multicolumn{3}{|l|}{$\mathrm{R}^{2}=0.497207$} \\
\hline \multicolumn{3}{|l|}{ Adj $R^{2}=0.400516$} \\
\hline \multicolumn{3}{|c|}{ Durbin-Watson $=1.870691$} \\
\hline \multicolumn{3}{|c|}{ Jarque-Bera $=[2.481210](0.289209)$} \\
\hline \multicolumn{3}{|c|}{ Wald Test $=[7.118528](0.0001)$} \\
\hline \multicolumn{3}{|c|}{ Breusch-Godfrey Serial Correlation LM Test $=[0.233687](0.7934)$} \\
\hline \multicolumn{3}{|c|}{ Heteroskedasticity Test: Breusch-Pagan-Godfrey $=[1.575603](0.1957)$} \\
\hline
\end{tabular}


results reveal that the coefficient of the error correction term (ECT); Coint Equation (1), is -0.610120 and is highly statistically significant at the 1 per cent level. This means that approximately 61 per cent of the disequilibria in private consumption owing to a shock to the system in the previous year can be corrected back to the long run equilibrium in the current period. Similar to the results of the estimated long-run model, private consumption in the short run is positively affected by national disposable income whose coefficient is 0.606 and is significant at the 1 per cent level. This means that a 1 per cent increase in national disposable income will result in a 0.606 per cent rise in private consumption in the short run. However, the long run impact of national disposable income on private consumption is greater than in the short run. This implies that Basotho prefer to save more in the short run than in the long run as income grows. This finding adds credence to the existence of the life cycle permanent income hypothesis in Lesotho. What is however surprising is that, the coefficient of the rate on deposits was found to be 0.007 in the short run and is significant at the 5 per cent level. Thus, a percentage increase in the rate on deposits results in a percentage rise in private consumption by approximately 0.007 per cent in the short run meaning that upticks in the rate on deposits are not enough to induce savings by households.

The coefficient of government expenditure $(-0.262)$ shows that government expenditure has a negative impact on private consumption in the short run. It is significant at the 1 per cent level. Thus, a percentage increases in government expenditure, results in a percentage reduction in private consumption by approximately 0.262 per cent in the short turn. The result is similar to the one in the long run. This crowding out of private consumption could be explained by the existence of a negative wealth effect induced by increased government expenditure. The coefficient of inflation in the short run, just like in the long run was found not to be statistically significant in determining private consumption. A possible explanation could be that private consumption benefits from inflation offsetting policies such as government subsidies.

\section{Discussion}

The study employed the ARDL bounds testing approach to cointegration to investigate the impact of national disposable income, inflation, government expenditure and the rate on deposits on private consumption in Lesotho over 1982-2015. Based on the research findings, national disposable income has a positive and highly significant impact on private consumption that is less than 1 in the short run and long run respectively. This confirms the existence of the Keynesian theory of consumption in Lesotho. The policy recommendation following these results is that the GoL should expeditiously implement initiatives aimed at increasing employment and private sector development as espoused in the country's National Strategic Development Plan (NSDP) 2012/13-2016/17. This will mean higher levels of disposable income and purchasing power which 
will translate into a sustainable consumption driven economic growth.

The study also showed that the impact of national disposable income on private consumption in the long run was higher than the impact in the short run. This could mean that more saving and less consuming is done in the short run than is done in the long run. This point supports the existence of the life cycle permanent income hypothesis in Lesotho. However, although small in size, increases in the rate on deposits positively affected private consumption in the short run. On the other hand, the impact was insignificant in the long run. These findings go against a priori expectations. The implication is that initiatives to increase the rate on deposits to attract savers and secure funds for investment in Lesotho in the long run and in the short run do not have the desired effect. Investment financing is therefore less likely to come from domestic banks and more likely to emanate from outside the country. The development of the domestic financial sector therefore becomes imperative. Policy makers are urged to ensure successful implementation of the Financial Sector Development Strategy (FSDS) that was adopted by the GoL as a working policy document during 2013/14. The FSDS encompasses, inter alia, the mobilisation of financial resources and the promotion of a savings culture, two key components in the nurturing of investment and sustainable economic growth.

The relationship between inflation and private consumption was found to be insignificant in the short run and in the long run. This is contrary to a priori expectations and it implies that increases in the level of inflation do not lessen the level of goods demanded in private consumption. A possible reason could be government subsidies that offset the negative impacts of inflation. According to [36], the GoL instituted agriculture input subsidies in the years 1980/1981 and 2003/2004. The subsidies were intended to achieve self-sufficiency and lower consumer prices of key staple foods such as maize, sorghum, wheat, beans and peas. Considering that food is the main consumption item in Lesotho and that most of the rural population's income emanates from the farming sector, the government is advised to identify and implement efficient and cost effective inflation offsetting policies such as subsidies, especially on key consumption items like food. The study also showed a negative relationship between government expenditure and private consumption in the short run and long run. The short run impact $(-0.262)$ is lower than the long run $(-0.429)$ impact. The policy recommendation would be for the government to pursue strategies aimed at financing increased levels of government expenditure through the broadening of the total revenue base.

\section{Conclusion}

The study has been successful in confirming the Keynesian theory of consumption in Lesotho as well as the existence of the life cycle permanent income hypothesis. In addition, the decision to include the government expenditure variable in the consumption function has resulted in a key finding: the presence of a neg- 
ative relationship between government spending and private consumption both in the short run and long run. This revelation is important since it presents the GoL with a better understanding of the effects of fiscal policy on the country's economy.

\section{References}

[1] Hall, R.E. (1987) Consumption. NBER Working Paper No. 2265, 1-30. https://doi.org/10.3386/w2265

[2] Parker, J. (2010) Theories of Consumption and Saving. Economics 314 Coursebook.

[3] Bayar, A. and McMorrow, K. (1999) Determinants of Private Consumption (No. 135). Directorate General Economic and Financial Affairs (DG ECFIN), European Commission, Brussels.

[4] Raut, L.K. and Virmani, A. (1989) Determinants of Consumption and Savings Behavior in Developing Countries. The World Bank Economic Review, 3, 379-393. https://doi.org/10.1093/wber/3.3.379

[5] Nikbin, B. and Panahi, S. (2016) Estimation of Private Consumption Function of Iran: Autoregressive Distributed Lag Approach to Co-Integration. International Journal of Economics and Financial Issues, 6, 653-659.

[6] Deaton, A. (1992) Understanding Consumption. Oxford University Press, Oxford. https://doi.org/10.1093/0198288247.001.0001

[7] Elköf, J.A. and Molapo, P. (1987) Distribution of Incomes and Consumption in Lesotho. A Study Based on the 1986/87 Household Budget Survey Data. Issue 4 of Staff Occasional Paper. Central Bank of Lesotho, Maseru.

[8] Chioma, N.J. (2009) Causal Relationship between Gross Domestic Product and Personal Consumption Expenditure of Nigeria. African Journal of Mathematics and Computer Science Research, 2, 179-183.

[9] Ofwona, A.C. (2013) An Estimation of the Consumption Function for Kenya Using Keynes' Absolute Income Hypothesis for the Period 1992-2011. Journal of Emerging Trends in Economics and Management Sciences, 4, 103.

[10] Apergis, N., Simo-Kengne, B. and Gupta, R. (2014) The Long-Run Relationship between Consumption, House Prices, and Stock Prices in South Africa: Evidence from Provincial-Level Data. Journal of Real Estate Literature, 22, 83-99.

[11] Sekantsi, L.P. (2016) Determinants of Real Private Consumption Expenditure in Lesotho. European Journal of Economics and Management, 3, 108-122.

[12] Bureau of Statistics (BoS) (2011) 2008 Lesotho Integrated Labour Force Survey. Bureau of Statistics (BoS), Lesotho.

[13] Bureau of Statistics (BoS) (2014) The 2010/11 Household Budget. Bureau of Statistics (BoS), Lesotho.

[14] Bureau of Statistics (BoS) (2006) The 2002/03 Household Budget. Bureau of Statistics (BoS), Lesotho.

[15] Guo, K. and N’Diaye, P.M.B. (2010) Determinants of China's Private Consumption: an International Perspective (No. 10-93). International Monetary Fund.

[16] Diacon, P.E. and Maha, L.G. (2015) The Relationship between Income, Consumption and GDP: A Time Series, Cross-Country Analysis. Procedia Economics and Finance, 23, 1535-1543. https://doi.org/10.1016/S2212-5671(15)00374-3

[17] Sakib-Bin-Amin (2011) Causal Relationship between Consumption Expenditure and Economic Growth in Bangladesh. World, 1, 158-169. 
[18] Genchev, E.R. (2012) Analysis of Income-Consumption Relationship in Bulgaria and Russia. Young Scientist, 4, 115-119.

[19] Akekere, J. and Yousuo, P.O.J. (2012) Empirical Analysis of Change in Income on Private Consumption Expenditure in Nigeria from 1981 to 2010. International Journal of Academic Research in Business and Social Sciences, 2, 188-197.

[20] Perotti, R. (2007) Fiscal Policy in Developing Countries: A Framework and Some Questions. Policy Research Working Paper 4365, World Bank, Washington DC.

[21] Bank, A. (2011) Effects of Discretionary Fiscal Policy: New Empirical Evidence for Germany. Discussion Paper, Wirtschaftswissenschaftliche Fakultät, Leibniz Universität Hannover, Hannover, 470.

[22] Mathewos, H. (2015) Effects of the Fiscal Policy Shocks under the Debt Feedback Rule in Ethiopia: Evidence from SVAR Model. Doctoral Dissertation, AAU.

[23] Katona, G. (1974) Psychology and Consumer Economics. Journal of Consumer Research, 1, 1-8. https://doi.org/10.1086/208575

[24] Casadio, P. and Paradiso, A. (2010) Inflation and Consumption in a Long Term Perspective with Level Shift.

[25] Nakagawa, S. and Oshima, K. (2000) Does a Decrease in the Real Interest Rate Actually Stimulate Personal Consumption? Review of Economic Studies, 60, 631-649.

[26] Elder, J. and Halvorsen, A. (2009) The Effect of a Cut in the Interest Rate on Consumption and Saving. Tax Policy and the Economy, Vol. 7, MIT Press, Cambridge.

[27] Kapoor, M. and Shamika, R. (2009) The Effect of Interest Rate on Household Consumption; Evidence from a Natural Experiment in India. Indian School of Business, Hyderabad.

[28] Pesaran, M.H., Shin, Y. and Smith, R.P. (1997) Pooled Estimation of Long-Run Relationships in Dynamic Heterogeneous Panels. University of Cambridge, Department of Applied Economics, Cambridge.

[29] Pesaran, M.H., Shin, Y. and Smith, R.P. (1999) Pooled Mean Group Estimation of Dynamic Heterogeneous Panels. Journal of the American Statistical Association, 94, 621-634. https://doi.org/10.1080/01621459.1999.10474156

[30] Pesaran, M.H., Shin, Y. and Smith, R.J. (2001) Bounds Testing Approaches to the Analysis of Level Relationships. Journal of Applied Econometrics, 16, 289-326. https://doi.org/10.1002/jae.616

[31] Nkoro, E. and Uko, A.K. (2016) Autoregressive Distributed Lag (ARDL) Cointegration Technique: Application and Interpretation. Journal of Statistical and Econometric Methods, 5, 63-91.

[32] Dickey, D.A. and Fuller, W.A. (1979) Distribution of the Estimators for Autoregressive Time Series with a Unit Root. Journal of the American Statistical Association, 74, 427-431.

[33] Dickey, D.A. and Fuller, W.A. (1981) Likelihood Ratio Statistics for Autoregressive Time Series with a Unit Root. Econometrica, 49, 1057-1072.

[34] Phillips, P.C. and Perron, P. (1988) Testing for a Unit Root in Time Series Regression. Biometrika, 75, 335-346. https://doi.org/10.1093/biomet/75.2.335

[35] Narayan, P.K. (2005) The Saving and Investment Nexus for China: Evidence from Cointegration Tests. Applied Economics, 37, 1979-1990. https://doi.org/10.1080/00036840500278103

[36] Ratii, M.L. (2016) The Welfare Impact of the Removal of Input Subsidies for Crop Production in Lesotho. Doctoral Dissertation, Stellenbosch University, Stellenbosch. 


\section{Appendix}

\section{1) Summary of Studies on Determinants of Private Consumption}

\begin{tabular}{|c|c|c|c|c|}
\hline $\begin{array}{c}\text { Author (s) } \\
\text { \& Year }\end{array}$ & $\begin{array}{c}\text { Country \& } \\
\text { Period }\end{array}$ & Methodology & Variables & Key Findings \\
\hline $\begin{array}{l}\text { Chioma } \\
(2009)\end{array}$ & $\begin{array}{l}\text { Nigeria. } \\
1994-2007\end{array}$ & $\begin{array}{l}\text { Ordinary } \\
\text { Least } \\
\text { Squares }\end{array}$ & GDP, Personal Consumption & $\begin{array}{l}\text { Changes in Nigeria's GDP had an } \\
\text { insignificant effect on the level of } \\
\text { personal consumption expenditure. }\end{array}$ \\
\hline $\begin{array}{l}\text { Guo and } \\
\text { N’Diaye } \\
(2010)\end{array}$ & $\begin{array}{l}\text { China. } \\
\text { 1980-2008 }\end{array}$ & $\begin{array}{l}\text { Generalized } \\
\text { Method of } \\
\text { Moments }\end{array}$ & $\begin{array}{l}\text { Private consumption as a share of GDP, } \\
\text { Household income as a share of GDP, } \\
\text { Public income as a share of GDP, Per } \\
\text { capita GDP, Real GDP growth, Real } \\
\text { interest rates, Inflation, Change in } \\
\text { terms of trade, Old age dependency ratio, } \\
\text { Change in real effective exchange rate, } \\
\text { Share of employment in services sector, } \\
\text { Measure of past foreign financing, } \\
\text { Measure of financial development }\end{array}$ & $\begin{array}{l}\text { positive and significant relationship } \\
\text { between private consumption and } \\
\text { GDP per capita, public consumption } \\
\text { (as a share of GDP), real GDP growth, } \\
\text { change in terms of trade and external } \\
\text { financing. } \\
\text { Relationship between private consumption } \\
\text { and real interest rate, old-age dependency } \\
\text { ratio, financial development, share of } \\
\text { employment in the service sector, change } \\
\text { in real effective exchange rate and household } \\
\text { income (as a share of GDP) was negative } \\
\text { and statistically significant. }\end{array}$ \\
\hline $\begin{array}{l}\text { Ofwona } \\
\text { (2013) }\end{array}$ & $\begin{array}{l}\text { Kenya. } \\
1992-2011\end{array}$ & $\begin{array}{l}\text { Ordinary } \\
\text { Least } \\
\text { Squares }\end{array}$ & Income, Household Consumption & $\begin{array}{l}\text { Keynesian consumption theory holds } \\
\text { for Kenya with a statistically significant } \\
\text { and positive MPC. }\end{array}$ \\
\hline $\begin{array}{l}\text { Apergis } \\
\text { et al. } \\
(2014)\end{array}$ & $\begin{array}{l}\text { South Africa. } \\
1995-2011\end{array}$ & $\begin{array}{l}\text { Panel } \\
\text { cointegration } \\
\text { techniques }\end{array}$ & $\begin{array}{l}\text { Provincial Consumption, } \\
\text { Housing and Stock Prices }\end{array}$ & $\begin{array}{l}\text { Positive and significant relationship } \\
\text { between provincial consumption and } \\
\text { housing prices and between provincial } \\
\text { consumption and stock prices. } \\
\text { MPC respective to stock wealth was } \\
\text { larger and much more significant than } \\
\text { that of housing wealth. }\end{array}$ \\
\hline $\begin{array}{l}\text { Diacon } \\
\text { and } \\
\text { Maha } \\
(2015)\end{array}$ & $\begin{array}{l}79 \text { countries, } \\
\text { divided into } \\
\text { low income, } \\
\text { middle income } \\
\text { and high } \\
\text { income. } \\
1980-2010 .\end{array}$ & $\begin{array}{l}\text { Panel } \\
\text { cointegration } \\
\text { techniques }\end{array}$ & $\begin{array}{l}\text { Private consumption per capita, net } \\
\text { national income per capita, GDP } \\
\text { per capita }\end{array}$ & $\begin{array}{l}\text { Positive relationship between } \\
\text { consumption and income. }\end{array}$ \\
\hline $\begin{array}{l}\text { Nikbin } \\
\text { and } \\
\text { Panahi } \\
(2016)\end{array}$ & $\begin{array}{l}\text { Iran. } \\
1978-2012\end{array}$ & ARDL & $\begin{array}{l}\text { Total private consumption, GDP, } \\
\text { Inflation }\end{array}$ & $\begin{array}{l}\text { Positive and statistically significant } \\
\text { relationship between the level of } \\
\text { private consumption and GDP. } \\
\text { Negative and significant relationship } \\
\text { between the level of inflation and } \\
\text { consumption. }\end{array}$ \\
\hline $\begin{array}{l}\text { Sekantsi } \\
(2016)\end{array}$ & $\begin{array}{l}\text { Lesotho. } \\
\text { 1982-2013 }\end{array}$ & ARDL & $\begin{array}{l}\text { Inflation, real private domestic } \\
\text { consumption, real gross domestic } \\
\text { product, real gross national income, } \\
\text { real household disposable income, } \\
\text { real prime lending rate, narrow } \\
\text { money, broad money }\end{array}$ & $\begin{array}{l}\text { Higher income associated with } \\
\text { higher private consumption. } \\
\text { Higher inflation reduces private } \\
\text { consumption. } \\
\text { Higher interest rates reduce private } \\
\text { consumption. }\end{array}$ \\
\hline
\end{tabular}


2) Breusch-Godfrey Serial Correlation LM Test

\begin{tabular}{|c|c|c|c|c|}
\hline F-statistic & 0.233687 & \multicolumn{2}{|c|}{ Prob. F(2,24) } & 0.7934 \\
\hline $\mathrm{Obs}^{\star} \mathrm{R}$-squared & 0.605996 & \multicolumn{2}{|c|}{ Prob. Chi-Square(2) } & 0.7386 \\
\hline \multicolumn{5}{|c|}{ Test Equation: } \\
\hline \multicolumn{5}{|c|}{ Dependent Variable: RESID } \\
\hline \multicolumn{5}{|c|}{ Method: ARDL } \\
\hline \multicolumn{5}{|c|}{ Sample: 19842015} \\
\hline \multicolumn{5}{|c|}{ Included observations: 32} \\
\hline \multicolumn{5}{|c|}{ No d.f. adjustment for standard errors \& covariance } \\
\hline \multicolumn{5}{|c|}{ Presample missing value lagged residuals set to zero. } \\
\hline Variable & Coefficient & Std. Error & t-Statistic & Prob. \\
\hline D(LPRICONS(-1)) & -0.077570 & 0.223557 & -0.346980 & 0.7316 \\
\hline $\mathrm{D}(\mathrm{LNDI})$ & 0.000487 & 0.155559 & 0.003129 & 0.9975 \\
\hline D(LGOVEXP) & 0.007892 & 0.082330 & 0.095858 & 0.9244 \\
\hline INFL & -0.000146 & 0.003120 & -0.046821 & 0.9630 \\
\hline $\mathrm{D}(\mathrm{DR})$ & 0.000157 & 0.002805 & 0.055900 & 0.9559 \\
\hline $\mathrm{D}(\mathrm{DR}(-1))$ & 0.000417 & 0.003386 & 0.123290 & 0.9029 \\
\hline $\operatorname{RESID}(-1)$ & 0.141808 & 0.290949 & 0.487398 & 0.6304 \\
\hline $\operatorname{RESID}(-2)$ & -0.105025 & 0.188407 & -0.557437 & 0.5824 \\
\hline R-squared & 0.018937 & \multicolumn{2}{|c|}{ Mean dependent var } & 0.000329 \\
\hline Adjusted R-squared & -0.267206 & \multicolumn{2}{|c|}{ S.D. dependent var } & 0.025792 \\
\hline S.E. of regression & 0.029034 & \multicolumn{2}{|c|}{ Akaike info criterion } & -4.028404 \\
\hline Sum squared resid & 0.020231 & \multicolumn{2}{|c|}{ Schwarz criterion } & -3.661970 \\
\hline Log likelihood & 72.45446 & \multicolumn{2}{|c|}{ Hannan-Quinn criter. } & -3.906941 \\
\hline Durbin-Watson stat & 1.952729 & & & \\
\hline
\end{tabular}

\section{3) J-B Normality Test}

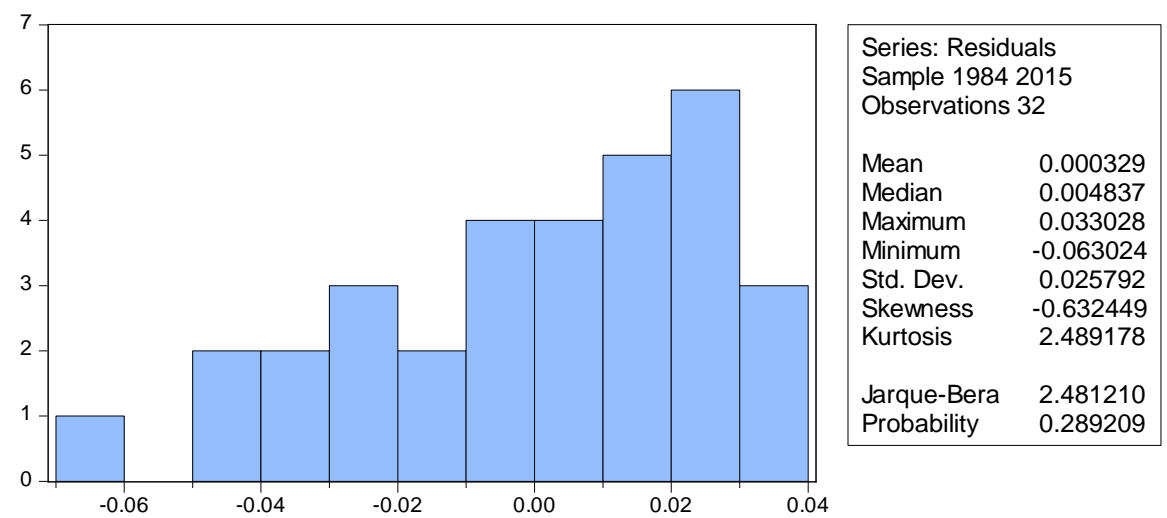


4) Heteroskedasticity Test: Breusch-Pagan-Godfrey

\begin{tabular}{|c|c|c|c|c|}
\hline F-statistic & 1.575603 & \multicolumn{2}{|c|}{ Prob. $F(6,25)$} & 0.1957 \\
\hline $\mathrm{Obs}^{\star} \mathrm{R}$-squared & 8.780377 & \multicolumn{2}{|c|}{ Prob. Chi-Square(6) } & 0.1863 \\
\hline Scaled explained SS & 4.221531 & \multicolumn{2}{|c|}{ Prob. Chi-Square(6) } & 0.6467 \\
\hline \multicolumn{5}{|c|}{ Test Equation: } \\
\hline \multicolumn{5}{|c|}{ Dependent Variable: RESID^^2 } \\
\hline \multicolumn{5}{|c|}{ Method: Least Squares } \\
\hline \multicolumn{5}{|c|}{ Sample: 19842015} \\
\hline \multicolumn{5}{|c|}{ Included observations: 32} \\
\hline \multicolumn{5}{|c|}{ No d.f. adjustment for standard errors \& covariance } \\
\hline Variable & Coefficient & Std. Error & t-Statistic & Prob. \\
\hline $\mathrm{C}$ & 0.001352 & 0.000351 & 3.856059 & 0.0007 \\
\hline D(LPRICONS(-1)) & -0.005025 & 0.004288 & -1.171798 & 0.2523 \\
\hline $\mathrm{D}(\mathrm{LNDI})$ & -0.006972 & 0.005057 & -1.378734 & 0.1802 \\
\hline D(LGOVEXP) & 0.001550 & 0.002213 & 0.700634 & 0.4900 \\
\hline INFL & $-6.32 \mathrm{E}-05$ & $8.08 \mathrm{E}-05$ & -0.782402 & 0.4413 \\
\hline $\mathrm{D}(\mathrm{DR})$ & -0.000106 & $8.05 \mathrm{E}-05$ & -1.316256 & 0.2000 \\
\hline $\mathrm{D}(\mathrm{DR}(-1))$ & $4.30 \mathrm{E}-05$ & $8.06 \mathrm{E}-05$ & 0.534161 & 0.5979 \\
\hline R-squared & 0.274387 & Mean c & dent var & 0.000645 \\
\hline Adjusted R-squared & 0.100240 & S.D. d & lent var & 0.000790 \\
\hline S.E. of regression & 0.000750 & Akaike & criterion & -11.36325 \\
\hline Sum squared resid & $1.41 \mathrm{E}-05$ & Schw & iterion & -11.04262 \\
\hline Log likelihood & 188.8119 & Hannan & nn criter. & -11.25697 \\
\hline F-statistic & 1.575603 & Durbin & tson stat & 2.304957 \\
\hline Prob(F-statistic) & 0.195670 & & & \\
\hline
\end{tabular}




\section{5) Ramsey RESET Test}

Equation: ARDL_WITH_NDI

Specification: D(LPRICONS) D(LPRICONS(-1)) D(LNDI) D(LGOVEXP)

INFL D(DR) D(DR(-1))

Omitted Variables: Squares of fitted values

$\begin{array}{cccc} & \text { Value } & \mathrm{df} & \text { Probability } \\ \text { t-statistic } & 0.223223 & 25 & 0.8252 \\ \text { F-statistic } & 0.049829 & (1,25) & 0.8252\end{array}$

F-test summary:

\begin{tabular}{|c|c|c|c|c|}
\hline & Sum of Sq. & df & \multicolumn{2}{|l|}{ Mean Squares } \\
\hline Test SSR & $4.10 \mathrm{E}-05$ & 1 & \multicolumn{2}{|l|}{$4.10 \mathrm{E}-05$} \\
\hline Restricted SSR & 0.020625 & 26 & \multicolumn{2}{|l|}{0.000793} \\
\hline Unrestricted SSR & 0.020584 & 25 & \multicolumn{2}{|l|}{0.000823} \\
\hline \multicolumn{5}{|c|}{ Unrestricted Test Equation: } \\
\hline \multicolumn{5}{|c|}{ Dependent Variable: D(LPRICONS) } \\
\hline \multicolumn{5}{|l|}{ Method: ARDL } \\
\hline \multicolumn{5}{|l|}{ Sample: 19842015} \\
\hline \multicolumn{5}{|c|}{ Included observations: 32} \\
\hline \multicolumn{5}{|c|}{ Maximum dependent lags: 2 (Automatic selection) } \\
\hline \multicolumn{5}{|c|}{ Model selection method: Akaike info criterion (AIC) } \\
\hline \multicolumn{5}{|c|}{ Dynamic regressors (1 lag, automatic): } \\
\hline \multicolumn{5}{|l|}{ Fixed regressors: } \\
\hline \multicolumn{5}{|c|}{ No d.f. adjustment for standard errors \& covariance } \\
\hline Variable & Coefficient & Std. Error & t-Statistic & Prob. ${ }^{*}$ \\
\hline D(LPRICONS(-1)) & 0.403590 & 0.154303 & 2.615561 & 0.0149 \\
\hline $\mathrm{D}(\mathrm{LNDI})$ & 0.637049 & 0.191402 & 3.328335 & 0.0027 \\
\hline D(LGOVEXP) & -0.274896 & 0.096931 & -2.836001 & 0.0089 \\
\hline INFL & -0.005410 & 0.003074 & -1.759957 & 0.0906 \\
\hline $\mathrm{D}(\mathrm{DR})$ & 0.007485 & 0.003180 & 2.353521 & 0.0268 \\
\hline $\mathrm{D}(\mathrm{DR}(-1))$ & -0.005339 & 0.003227 & -1.654564 & 0.1105 \\
\hline FITTED^2 & -1.654243 & 6.550199 & -0.252549 & 0.8027 \\
\hline R-squared & 0.498207 & \multicolumn{2}{|c|}{ Mean dependent var } & 0.014930 \\
\hline Adjusted R-squared & 0.377776 & \multicolumn{2}{|c|}{ S. D. dependent var } & 0.036376 \\
\hline S.E. of regression & 0.028694 & \multicolumn{2}{|c|}{ Akaike info criterion } & -4.073608 \\
\hline Sum squared resid & 0.020584 & \multicolumn{2}{|c|}{ Schwarz criterion } & -3.752979 \\
\hline Log likelihood & 72.17773 & \multicolumn{2}{|c|}{ Hannan-Quinn criter. } & -3.967329 \\
\hline Durbin-Watson stat & 1.874235 & & & \\
\hline
\end{tabular}


6) CUSUM and CUSUMQ tests for parameter constancy Plot of Cumulative Sum of Recursive Residuals:

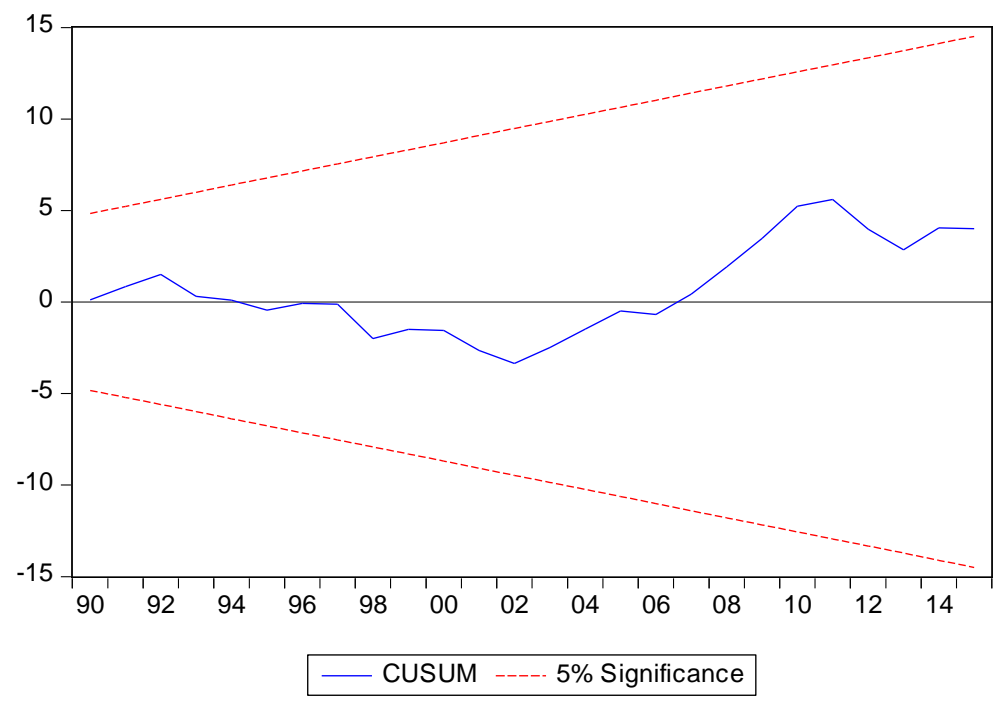

Plot of Cumulative Sum of Squares of Recursive Residuals:

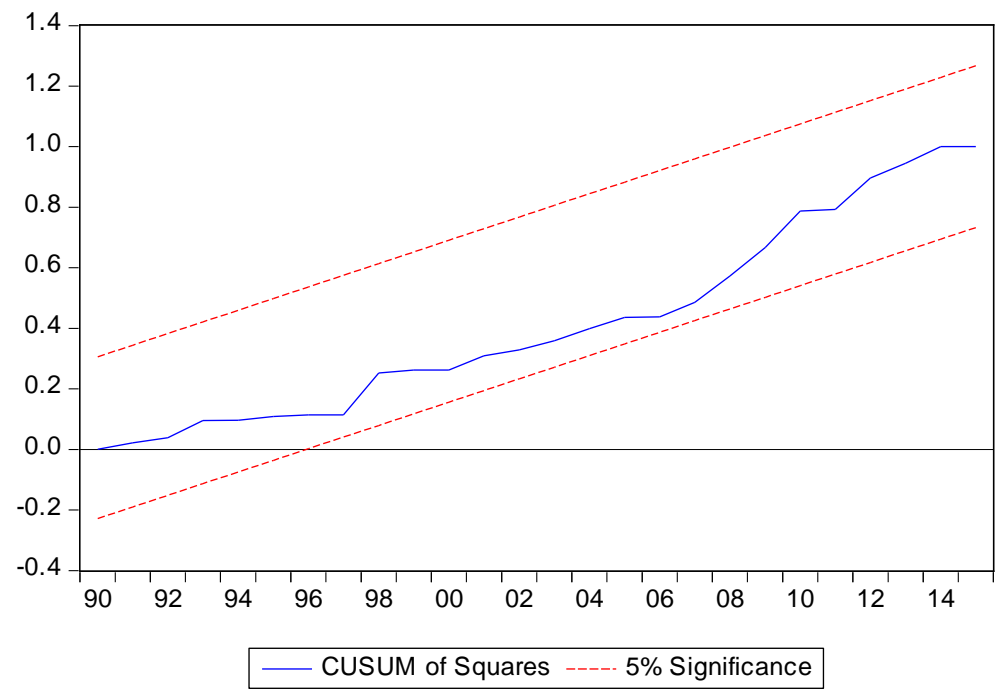

